University of Nebraska - Lincoln

DigitalCommons@University of Nebraska - Lincoln

Roman L. Hruska U.S. Meat Animal Research

U.S. Department of Agriculture: Agricultural Center

Research Service, Lincoln, Nebraska

2003

Molecular Cloning and Endometrial Expression of Porcine Amphiregulin

Jong G. Kim

USDA-ARS

Jeffrey L. Vallet

USDA-ARS

Ronald K. Christenson

USDA-ARS

Follow this and additional works at: https://digitalcommons.unl.edu/hruskareports

Kim, Jong G.; Vallet, Jeffrey L.; and Christenson, Ronald K., "Molecular Cloning and Endometrial Expression of Porcine Amphiregulin" (2003). Roman L. Hruska U.S. Meat Animal Research Center. 226. https://digitalcommons.unl.edu/hruskareports/226

This Article is brought to you for free and open access by the U.S. Department of Agriculture: Agricultural Research Service, Lincoln, Nebraska at DigitalCommons@University of Nebraska - Lincoln. It has been accepted for inclusion in Roman L. Hruska U.S. Meat Animal Research Center by an authorized administrator of DigitalCommons@University of Nebraska - Lincoln. 


\title{
Molecular Cloning and Endometrial Expression of Porcine Amphiregulin
}

\author{
JONG G. KIM, JEFFREY L. VALLET, AND RONALD K. CHRISTENSON* \\ U.S. Department of Agriculture, Agricultural Research Service, Roman L. Hruska U.S. Meat Animal Research Center, \\ Clay Center, Nebraska
}

\begin{abstract}
The porcine amphiregulin gene was previously reported to be within the quantitative trait locus (QTL) for uterine capacity on chromosome 8. Because amphiregulin stimulates cell proliferation, the amphiregulin gene might be responsible for this QTL. The objectives of this study were to clone amphiregulin cDNA and compare endometrial expression of its mRNA in pregnant Meishan (M) and White composite (WC) pigs. We obtained two amphiregulin cDNAs, one with 1,221 bp and another with 1,109 bp. The 112 bp difference corresponded to exon 5 of the human amphiregulin gene, which codes for the cytoplasmic domain. Endometrial mRNA expression of amphiregulin was significantly lower in $\mathrm{M}$ pigs than in WC pigs during early pregnancy (day 15-40 of gestation). Amphiregulin mRNA expression in the endometrium of both $M$ and $W C$ pigs increased $(P<0.01)$ from days 15 to 20 , decreased $(P=0.01)$ from days 20 to 30 , and did not change between days 30 and 40 . This may result in reduced amphiregulin protein production leading to the slower development of $\mathrm{M}$ conceptuses, contributing to greater uterine capacity and litter size in prolific Chinese $M$ pigs. Porcine genomic sequences isolated from a bacterial artificial chromosome genomic library contained exon 5 , suggesting that the deletion of exon 5 in the mRNA may be due to differential splicing. The amphiregulin gene consisted of six exons and five introns spanning 10.3 kb. Mol. Reprod. Dev. 65: 366-372, 2003. (c) 2003 Wiley-Liss, Inc.
\end{abstract}

Key Words: uterine capacity; gene expression; differential splicing

\section{INTRODUCTION}

Uterine capacity contributes to litter size in swine (Christenson et al., 1987). A quantitative trait locus (QTL) for uterine capacity has been identified near $71 \mathrm{cM}$ (95\% confidence interval 53-107 cM) on chromosome 8 in a population of $1 / 2$ Meishan (M), 1/2 White composite (WC) gilts (Rohrer et al., 1999). The beneficial allele originated from $\mathrm{M}$ gilts and substitution of a $\mathrm{M}$ allele for a WC allele was estimated to increase uterine capacity by approximately two pigs per litter (Rohrer et al., 1999).
Studies in M pigs have suggested that the greater fertility of this breed is associated with reduced conceptus growth rate. Embryos, placentas, and fetuses have been reported to be smaller in M pigs, and these differences have been suggested to be beneficial to uterine capacity by decreasing both the space taken up in the uterus and the nutrients required from the uterus to maintain each fetus (Christenson, 1993; Wilson et al., 1998; Vallet et al., 2002). Thus, genes influencing growth rate of the conceptus that lie within the QTL region of chromosome 8 may be candidate genes responsible for the QTL.

One such gene is amphiregulin. Amphiregulin is a glycoprotein that is a member of the epidermal growth factor (EGF) family. It binds to EGF receptor with lower affinity than EGF (Shoyab et al., 1989). The amphiregulin gene maps to within the uterine capacity QTL (Kim et al., 2002). It is also expressed by the porcine conceptus (Kennedy et al., 1993). Thus, chromosomal location, its expression by the conceptus, and its potential growth modulating activity make it a good candidate gene for the uterine capacity QTL. To further explore this possibility, the objectives of this study were to clone the complete coding region for porcine amphiregulin and compare endometrial amphiregulin mRNA expression in $\mathrm{M}$ and $\mathrm{WC}$ pigs.

\section{MATERIALS AND METHODS Cloning of a Partial Amphiregulin cDNA and Screening of an Expressed Sequence Tag Library}

Both $\mathrm{M}$ and WC gilts were slaughtered on day 30 of gestation and the uterus was recovered. Endometrium was collected and snap frozen in liquid nitrogen. Total RNA was then isolated from the endometrial samples of

Mention of trade names or commercial products in this article is solely for the purpose of providing specific information and does not imply recommendation or endorsement by the U.S. Department of Agriculture.

*Correspondence to: Ronald K. Christenson, USDA, ARS, U.S. Meat Animal Research Center, State Spur 18D, P.O. Box 166, Clay Center, Nebraska 68933-0166. E-mail: christenson@email.marc.usda.gov

Received 13 January 2003; Accepted 11 March 2003

Published online in Wiley InterScience (www.interscience.wiley.com) DOI 10.1002/mrd.10314 
WC gilts using the RNeasy kit (Qiagen, Santa Clarita, CA). To obtain a partial clone, $2 \mu \mathrm{g}$ of total RNA was used for reverse-transcription (RT) with reverse primer 2 in a $20-\mu l$ reaction, and then $1 \mu \mathrm{l}$ of the resultant product was amplified with all possible pairs of forward (F1-4) and reverse (R1-4) primers (Table 1). Polymerase chain reaction (PCR) was performed in a $10-\mu l$ reaction volume using 30 cycles of $95^{\circ} \mathrm{C}$ for $1 \mathrm{~min}, 58^{\circ} \mathrm{C}$ for $1 \mathrm{~min}$, and $68^{\circ} \mathrm{C}$ for $1 \mathrm{~min}$. Primer design was based on the known human cDNA sequence (Plowman et al., 1990). Amplification with F3 and R4 resulted in a 479-bp PCR product. This 479 bp product was cloned into pCRII vector (Invitrogen, Carlsbad, CA) and sequenced. The "Meat Animal Research Center 2 PIG" (MARC 2PIG) porcine expressed sequence tag (EST) library, which had been constructed using tissues from both M and WC pigs (Fahrenkrug et al., 2002), was then screened by PCR with primers based on the sequence of this clone. Because iterative screening of the EST library revealed a clone for amphiregulin without a region corresponding to exon 5 of the human amphiregulin gene, experiments were undertaken to investigate this further.

\section{Cloning of Amphiregulin cDNA From M and WC Endometrium}

To determine whether mRNAs from the endometrium of WC and $\mathrm{M}$ gilts contained the region corresponding to exon 5 of the human amphiregulin gene, RT-PCR was performed using total RNA from endometrium collected from day-30 pregnant WC and M gilts. In WC gilts, total RNA $(2 \mu \mathrm{g})$ was used for RT with primer R2. The resultant product $(1 \mu \mathrm{l})$ was amplified by PCR with primers $\mathrm{F} 6$ and R7, followed by the nested primers, F4 and R5. A minor 314 bp product and a major $202 \mathrm{bp}$ product were obtained. Each was cloned into pCRII vector (Invitrogen), and three clones for each form were sequenced in both directions. In $\mathrm{M}$ gilts, primers for RT-PCR were chosen to generate smaller products than the primers used for RT-PCR in WC gilts while still encompassing the deleted region. This was done so that electrophoresis would separate the two products more definitively. In M gilts, total RNA (2 $\mu \mathrm{g})$ was used for RT with primer R6. The resultant product $(1 \mu \mathrm{l})$ was amplified by PCR using primers F6 and R6, followed by the nested primers, F7 and R5. A minor $291 \mathrm{bp}$ product and a major $179 \mathrm{bp}$ product were cloned into pCRII vector. Three clones each were sequenced in both directions. The same sets of primers used for RT-PCR in $M$ gilts were then used to demonstrate whether both forms of amphiregulin mRNA are expressed in the endometrium from $\mathrm{M}$ and $\mathrm{WC}$ gilts ( $\mathrm{n}=4$ each).

\section{Confirmation of the Full Coding Region of Both Forms of Amphiregulin cDNA From $M$ and WC Endometrium}

To obtain the full coding region of the amphiregulin cDNA within each breed, RT-PCR was performed using total RNA from endometrium of $\mathrm{M}$ and $\mathrm{WC}$ gilts $(\mathrm{n}=4$ each). Total RNA ( $2 \mu \mathrm{g})$ was used for RT with primer R6 and the resultant product $(1 \mu \mathrm{l})$ was amplified by four rounds of nested primers. The nested primers used were F5 and R6 (1st round), F8 and R8 (2nd round), F8 and R7 (3rd round), and F1 and R7 (4th round). Isolated bands were purified and cloned into pCRII vector. Both longform (containing the full coding region) and short-form (lacking a region corresponding to exon 5) clones from $\mathrm{M}$

TABLE 1. Primers Used in the Characterization of the Porcine Amphiregulin

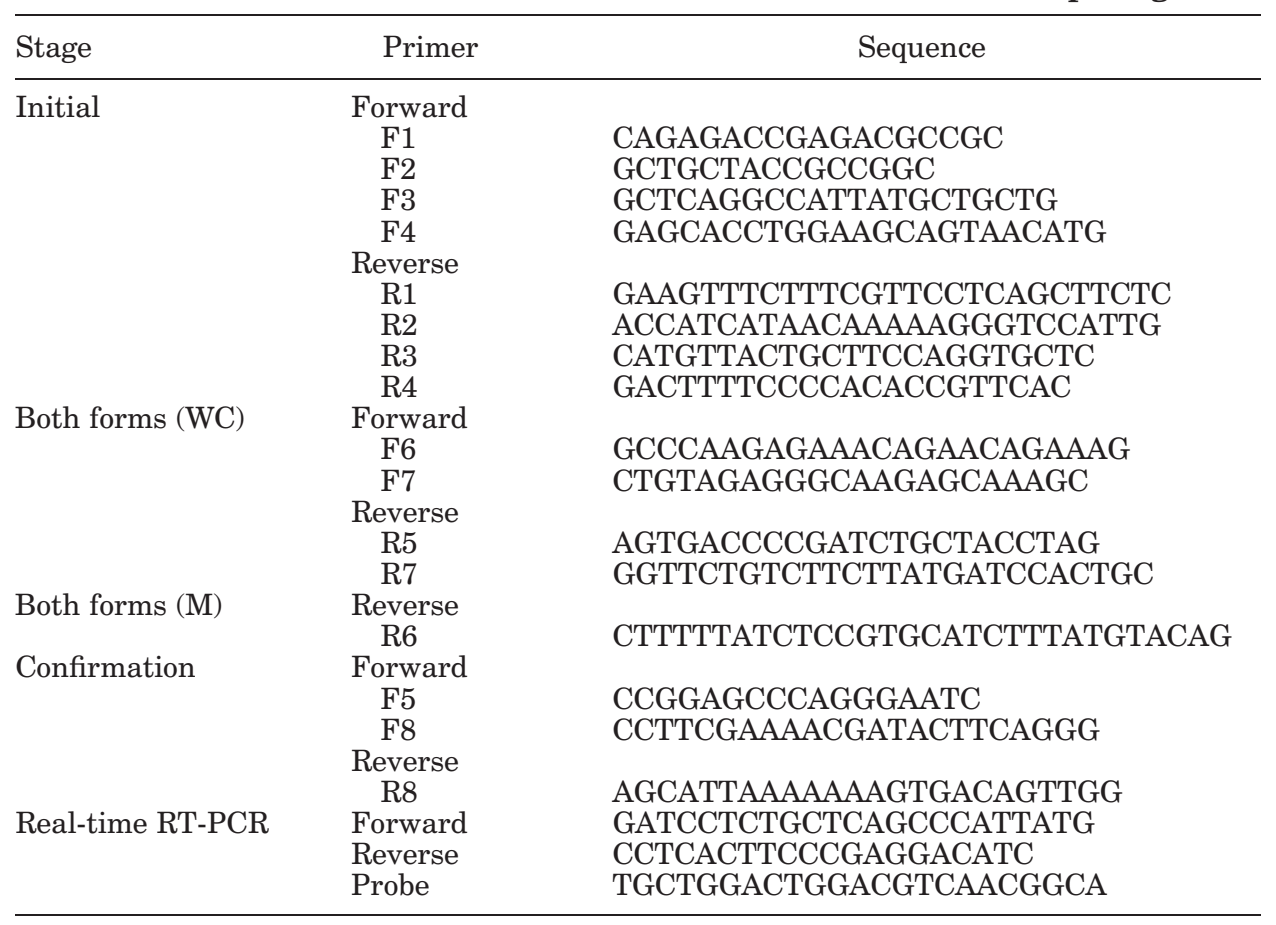


(four long- and two short-form clones from two gilts) and WC (seven long- and one short-form clones from three gilts) were sequenced in both directions.

\section{Expression of Amphiregulin mRNA in the Endometrium of $M$ and WC Pigs}

Endometrium was collected on days 15, 20, 30, and 40 of pregnancy from M and WC pigs (gilts and sows) and total RNA was isolated from endometrium using cesium chloride gradient purification. To measure specific mRNA, real-time RT-PCR was performed using the one step RT-PCR kit (Applied Biosystems, Foster City, CA) and $100 \mathrm{ng}$ of total RNA ( $\mathrm{n}=4$ to 5 pigs per day) with an ABI Prism 7700 (Applied Biosystems) according to the manufacturer's protocol. To standardize the realtime RT-PCR procedure, 25, 50, 100, 200, and $400 \mathrm{ng}$ of total RNA from endometrium collected on day 20 of pregnancy was assayed for glyceraldehyde-3-phosphate dehydrogenase (GAPDH) and amphiregulin mRNA within each assay. TaqMan fluorescent probes for GAPDH and amphiregulin labeled with 6-carboxy4,7,2',7'-tetrachloro-fluorescein (TET) and 6-carboxyfluorescein (FAM), respectively, were used to detect the respective mRNAs. Standard curves were calculated for each mRNA arbitrarily setting the $25,50,100,200$, and $400 \mathrm{ng}$ of total RNA as $1,2,4,8$, and $16 \mathrm{U}$, respectively, and then plotting the threshold cycle versus log of the arbitrary units as suggested by the manufacturer's protocol. Amphiregulin (Table 1) and GAPDH primers were designed based on the porcine amphiregulin clone cDNA sequence and porcine GAPDH (GenBank accession no. AF017079), respectively. GAPDH results were included as a covariate in subsequent analyses of amphiregulin mRNA to correct for differences in RNA sample dilutions. Thermal cycling conditions were $48^{\circ} \mathrm{C}$ for $30 \mathrm{~min}$ and $95^{\circ} \mathrm{C}$ for $10 \mathrm{~min}$, followed by 40 cycles of $95^{\circ} \mathrm{C}$ for $15 \mathrm{sec}$ and $60^{\circ} \mathrm{C}$ for $1 \mathrm{~min}$.

\section{Screening of Bacterial Artificial Chromosome Library and Sequencing}

The RPCI-44 male porcine bacterial artificial chromosome (BAC) genomic library (BACPAC Resources, Buffalo, NY) was screened using a 1,000-bp cDNA probe. The probe was generated by PCR with primers F7 and R7 using the short form amphiregulin cDNA obtained from the EST library as template. Two positive BAC clones (197A1 and 199P1) were digested with EcoRI or PstI, blotted onto nylon membrane, and hybridized using the same cDNA probe for amphiregulin. After autoradiography, both BAC clones displayed the same positive bands. A $1.7 \mathrm{~kb}$ EcoRI fragment was subcloned into EcoRI digested pBluescript II SK vector and sequenced. PstI fragments of 5 and $4 \mathrm{~kb}$ were subcloned into PstI digested pBluescript II SK vector and sequenced. A positive $3.4 \mathrm{~kb}$ EcoRI/XbaI fragment was subcloned into pBluescript II SK vector digested with EcoRI/XbaI and sequenced. Primers were designed to amplify the remaining regions: (1) from a part of intron 1 to a part of exon 3, including exon 2 and intron 2 , and (2) a part of intron 4. Amplified products were cloned into pCRII vector and sequenced.

\section{Statistical Analysis}

Expression of amphiregulin mRNA was analyzed by the General Linear Models procedure of the statistical analysis system (SAS Institute, Inc., Cary, NC) after the data were log transformed to decrease heterogeneity of variance between breed-day combinations. The logtransformed amphiregulin mRNA data were analyzed with and without correction using the units of GAPDH mRNA as a covariate. The model included effects of day, breed, assay, and the day-by-breed interaction.

\section{RESULTS \\ Identification of a Porcine Amphiregulin Clone}

A clone containing the full coding region for porcine amphiregulin was obtained from the MARC 2PIG EST library, but it lacked a region corresponding to exon 5 of the human amphiregulin gene. Further cloning by RTPCR and sequencing of the clones revealed that two forms of porcine amphiregulin mRNAs, one with and one without the 112-bp region corresponding to exon 5 of the human amphiregulin gene, were present in the endometrium of $\mathrm{M}$ and WC gilts on day 30 of pregnancy. Consistent with this, a $1,221 \mathrm{bp}$ long form and an 1,109 bp short form (GenBank accession no. AY028310 and AY028311, respectively) of porcine amphiregulin cDNA were obtained. Nucleotide sequences and predicted amino acid sequences for both forms of the putative porcine amphiregulin are shown in Figure 1. The short form of amphiregulin mRNA lacking the region corresponding to exon 5 of the human amphiregulin gene appeared to be the predominant form (Fig. 2). There were no consistent differences in the amphiregulin cDNA sequences derived from $M(n=2$ gilts) and WC ( $\mathrm{n}=3$ gilts) in either the long or short forms. The long form of porcine amphiregulin cDNA has an open reading frame of $741 \mathrm{bp}$ that encodes 247 amino acids compared to $753 \mathrm{bp}$ and 251 amino acids for the human amphiregulin cDNA, and $746 \mathrm{bp}$ and 249 amino acids for the mouse amphiregulin cDNA. The $5^{\prime}$ and $3^{\prime}$ untranslated regions (UTR) of the porcine cDNAs were 200 and $291 \mathrm{bp}$, respectively. The sequence identity of the $5^{\prime}$ UTR of porcine amphiregulin cDNA with those of mouse, rat, and human ranged from 52 to $65 \%$. The sequence identity of the $3^{\prime}$ UTR of porcine amphiregulin cDNA with the $3^{\prime}$ UTR of the other three species ranged from 69 to $89 \%$. Multiple sequence alignment showed no consensus regions in the $5^{\prime}$ UTR. However, there were consensus sequences in the $3^{\prime}$ UTR surrounding ATTTA sequences, a motif previously reported to destabilize mRNA (Shaw and Kamen, 1986). Four ATTTA repeat sequences are located in the $3^{\prime}$ UTR of pig, human, mouse, and rat sequences. There was a polyadenylation signal of ATTAAA 12 bp upstream from the polyA tail, which was also conserved. There were three potential N-glycosylation sites (Fig. 1), and these are conserved in 
GCTGCTGCCGCCGGCGCCCGTGGTGCTGTCACTCTTGATCCTCTGCTCAGCCCATTATGCTGCTGGACTGGACGTCAACGGCACCTCCTCTGGGAAAGGA

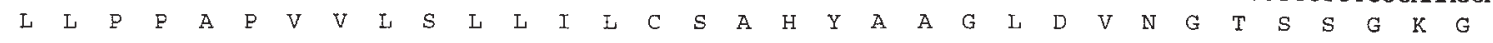
GAACCATTTTCTGGGGACCA TGGTGCTGAGGCATTTGAGG TGACCTCCAG AAGTGAGATG TCCICGGGAAGTGAGGCTCC CCCTG CTAGCGAAATGCCTT

GTTCCTCTTTGCAGTGGATCATAAG AAGACAGAACCTTTTTGTTCTGGTGGTTTTAAACT TCCAACTGTCACTTTTTTTAATGCTAAGTCTTATTTCTGT GTTCCTCTTTGCAGTGGATCATAAGAAGACAGAACCTTTTTGTTCTGGMGTTTTAAACT TCCAACTGTCACTTTTTTTAATGCTAAGTCTTATTTCTGT $\downarrow$ $\downarrow$

ACATAAAGATGCACGGAGATAAAAAGTATTTTTTCAAGTTGTAAA TAATTTATTTAATATTTAATGGAAG TGTATTTATTTTACAGTTCATTAAACTTTT ACATAAAGATGCA GGGAGATAAAAAGTATT TTTTCAAGTT GTAAATAATTTATTTAATATTTAATGGAAG TGTATTTATTTTACAGTTCA TTAAACTTTT

Fig. 1. The nucleotide sequences and predicted amino acid sequences for the putative porcine amphiregulin precursors are shown. The cDNA sequences of the short (S) and long (L) forms of the porcine amphiregulin differ in a 112 bp region (indicated by -----). A 47 bp AT-rich region (44 AT and 3 GC) is indicated by two arrows $(\downarrow)$. Four ATTTA repeat sequences in the $3^{\prime}$ UTR are underlined. A consensus polyadenylation signal of ATTAAA is shown in bold, italicized letters. Three possible Asn-linked glycosylation sites are indicated with *

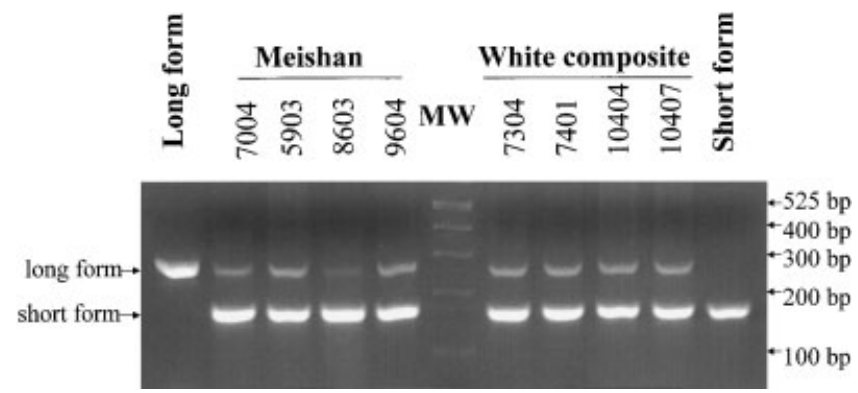

Fig. 2. Two different forms of amphiregulin mRNAs were present in both Meishan (M) and White composite (WC) pig endometrium on day 30 of pregnancy $(\mathrm{n}=4$ each) as shown by reverse transcriptionpolymerase chain reaction (PCR). The short form appeared to be the predominant form in both breeds. Arrows $(\rightarrow)$ on the left indicate the bands resulting from amplification of the long and short forms of amphiregulin cDNAs. Molecular weight (MW) markers are shown in the middle. Arrows $(\leftarrow)$ on the right indicate MW markers of 525 (appearing close together with 500-bp), 400, 300, 200, and 100-bp. humans (Plowman et al., 1990); however, only the first two N-glycosylation sites are conserved in rodents (Kimura et al., 1990; Das et al., 1995) and in sheep (Forsyth et al., 1997). A 47-bp AT-rich region (44 AT and $3 \mathrm{GC}$ ) is present in the $3^{\prime}$ UTR of the porcine amphiregulin cDNA.

Percent identities between the amino acid sequences of pig and human (Plowman et al., 1990), mouse (Das et al., 1995), or rat (Kimura et al., 1990) amphiregulin precursors are 83, 71, and 67\%, respectively. The encoded amino acid sequence of porcine amphiregulin cDNA is aligned with those of human, mouse, and rat amphiregulin precursors in Figure 3. Five structural domains are predicted in the porcine amphiregulin precursor based on the sequence of the human amphiregulin precursor (Plowman et al., 1990): a signal peptide (aa 1-19); an amino terminal pro-region (aa 20-94); mature amphiregulin (aa 95-178, EGF-like domain 138-178); a transmembrane domain (aa 193-216); and a cytoplasmic domain (aa 217-247). Cysteine residues are conserved in the EGF-like domains of porcine 
$\mid \rightarrow$ signal peptide $\leftarrow \rightarrow$

pshort

plong

human

mouse

rat MRAPLIPPAP VVLSLLILCS AHYAAGLDVN GTSSGKGEPF SGDHGAEAFE VTSRSEMSSG SEAPPASEMP SGS ......D YDYAEEYDNE PHISGYIVDD

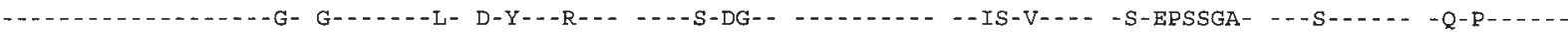

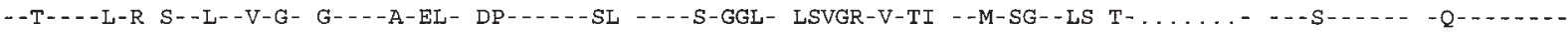

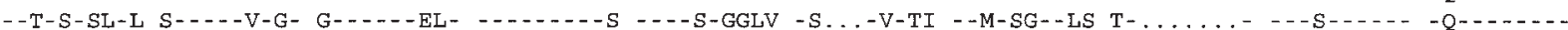

101

151

200

$\rightarrow$ amphiregulin mature peptide

PShOrt SVRVEOVVKP KRNRTESENT SDKPKRKKKG GKSGKNRRN. RKKKNPCDAE FONFCIHGDC KYIEHLEAVT CKCYODYFGE RCGEKSMKTH TMVHSDLSKI plong SVRVEQVVKR RRNRTESENT SDKPRRKRKG GKSGKNRRN. RKKRNPCDAE FQNFCIHGDC KYIEHLEAVT CRCYQDYFGE RCGEKSMKTH TMVHSDLSKI human -...... PQ-K-...

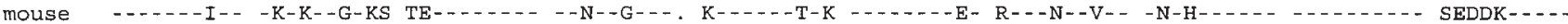

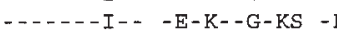

201 256

transmembrane domain $\leftarrow \rightarrow$ cytoplasmic domain $\leftarrow$ pshort ALAAIAAFVS AMSFTA. IA VVITI plong AIAAIAAFVS AMSFTA.. IA VVITIYLRKR YFREYEGAAE ERKKLRQENA NAHAIA

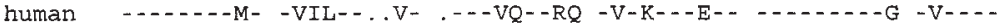
mouse -VV-VTI-.- -IILA-IG-G I-_-VH-W-- -.---ET- --RR-.--G TV-.. rat $\quad \ldots-$ IV $---V-V A-\ldots-G$ IITAVL-.- F-..-.E-. - RR-..-G T-...

Fig. 3. A comparison of the predicted amino acid sequences for putative porcine amphiregulin precursor with human, mouse, and rat amphiregulin sequences is shown. Bold letters represent the coding region corresponding to mature amphiregulin. The beginning $(\mid \rightarrow)$ and the end $(\leftarrow \mid)$ of each domain are indicated.

amphiregulin, EGF (Kim et al., 2001), and TGF- $\alpha$ (Vaughan et al., 1993) (Table 2). The region comprised of predominantly basic residues, thought to be involved in heparin-binding ability (Thorne and Plowman, 1994), is also well conserved. The porcine amino terminal domain contained 75 residues compared to 81 residues in the human and 74 residues in the mouse. Both porcine and rat transmembrane domains contained 24 residues compared to 23 residues in the human and 26 residues in the mouse.

\section{Expression of Amphiregulin mRNA in the Endometrium of $M$ and WC Pigs}

Analysis of real-time RT-PCR data indicated that there were significant day $(P<0.01)$ and breed $(P<0.01)$ effects with no day-by-breed interaction. Amphiregulin mRNA expression in the endometrium of both $\mathrm{M}$ and $\mathrm{WC}$ pigs increased $(P<0.01)$ from days 15 to 20 , decreased $(P=0.01)$ from days 20 to 30 , and did not change between days 30 and 40 (Fig. 4). Amphiregulin mRNA expression was lower in M pigs than WC pigs throughout the days measured.

There was no difference between the M (mean $2.40 \pm 0.25$ arbitrary units) and WC $(2.39 \pm 0.25)$ pigs in overall GAPDH mRNA expression as determined by real-time RT-PCR. However, GAPDH mRNA expression did change across the days of gestation studied. It increased $(P=0.02)$ from day $15(1.98 \pm 0.33)$ to day 20
$(3.19 \pm 0.33)$, did not change on day $30(2.68 \pm 0.37)$, and tended to decrease $(P=0.08)$ on day $40(1.73 \pm 0.33)$. There was no day-by-breed interaction. Therefore, it is statistically valid to adjust amphiregulin mRNA expression across day of gestation using GAPDH as a covariate.

When amphiregulin mRNA expression was statistically adjusted using GAPDH mRNA expression as a covariate, the changes in amphiregulin mRNA expression became smaller, but were still significant. The adjusted values of amphiregulin mRNA expression on days $15,20,30$, and 40 were $0.31,2.61,1.36$, and 0.95 for $\mathrm{M}$ pigs and $1.34,6.93,1.49$, and 2.31 for $\mathrm{WC}$ pigs, respectively. These adjusted amphiregulin mRNA expression values still depicted significant day (of gestation) and breed effects (Fig. 4).

\section{Sequencing of BAC Subclones}

The porcine amphiregulin gene sequence was derived from the positive subclones after restriction enzyme digestion of a clone containing the amphiregulin gene from the porcine BAC library, and the sequence obtained was compared with the human amphiregulin gene sequence. The exons of the amphiregulin gene in both species were homologous. An EcoRI digested $1.7 \mathrm{~kb}$ fragment contained a part of exon 3 , intron 3 , exon 4 , and a part of intron 4 (Fig. 5). The $5 \mathrm{~kb}$ PstI fragment contained the region $5^{\prime}$ of the amphiregulin gene, exon 1 , and a part of intron 1 . The PstI digested $4 \mathrm{~kb}$ fragment

TABLE 2. Cysteine Residues Conserved in the EGF-Like Domains of Porcine EGF Family Growth Factors Are Shown in Bold Letters; Other Conserved Amino Acids Are Underlined

\begin{tabular}{|c|c|}
\hline $\begin{array}{l}\text { Amphiregulin } \\
\text { EGF }\end{array}$ & $\begin{array}{l}\text { CDAEFQNFCIHGD-CKY IEHLEAVTCKCYQDYFGERCGEK } \\
\text { CPPSHDGYCLHGG VCMYIEAVDSYA C NCVFGYVGERCQHR }\end{array}$ \\
\hline TGF- $\alpha$ & CPDSHSQFCF HGT-CR F LVQEDKPACVCHSGYY VGARCEHA \\
\hline
\end{tabular}




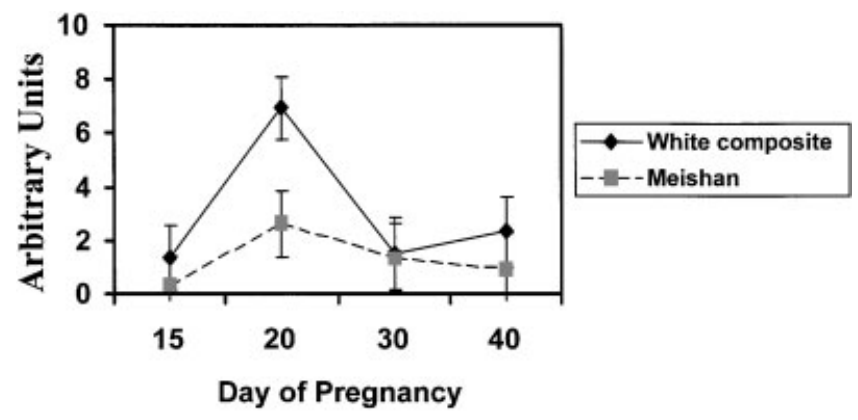

Fig. 4. Least-square means ( \pm standard error means) of arbitrary units, adjusted using GAPDH, from real-time RT-PCR for amphiregulin mRNA in endometrium of $\mathrm{M}$ and WC pigs during early pregnancy are illustrated. WC pigs had higher $(P<0.01)$ amphiregulin mRNA expression than $\mathrm{M}$ pigs. Amphiregulin mRNA expression increased significantly $(P<0.01)$ from day 15 to 20 of pregnancy, decreased from days 20 to $30(P=0.01)$, but did not change between days 30 and 40 .

contained a part of intron 4 , exon 5 , intron 5 , exon 6 , and the $3^{\prime}$ flanking region (Fig. 5). A positive $3.4 \mathrm{~kb}$ EcoRI/ XbaI fragment contained a part of intron 1, exon 2, intron 2, and a part of exon 3. Alignment of these sequences, along with the sequences obtained from PCR amplification and cloning, revealed the gene structure consisted of six exons and five introns and exon-intron organizations (Fig. 5). In the long form, exon 4 is spliced to exon 5. However, in the short form, exon 4 is spliced to exon 6 , causing a frame shift. The resulting stop codon TAG predicts that the resulting protein lacks the cytoplasmic domain (Table 3).

Amplification of the variant region (a part of intron 4, exon 5, intron 5, and a part of exon 6) by PCR using genomic DNA of $\mathrm{M} \times \mathrm{WC}$ crossbred pigs $(\mathrm{n}=12)$ as template followed by Southern blotting resulted in a single band matching the size of the full genomic sequence. This result confirms that no gene duplication or deletion of exons at the genome level is present in the pigs examined (data not shown).

\section{DISCUSSION}

This is the first report of the full coding region for porcine amphiregulin cDNA. In addition, two forms of mRNA were observed in pig endometrium. The short form of the amphiregulin mRNA would result in an amphiregulin precursor protein that lacks the cytoplasmic domain due to differential splicing of exon 5. Finally, the expression of amphiregulin mRNA in the endometrium was elevated $(P<0.01)$ on day 20 of pregnancy compared to day 15 and was lower $(P<0.01)$ in M pigs compared to WC pigs on all days examined.

Several molecular weight forms of amphiregulin, which differ in glycosylation and in $\mathrm{N}$-terminal peptide core length, have been reported in humans (Johnson et al., 1993). However, the presence of a naturally occurring amphiregulin that is missing the cytoplasmic domain has not been reported. The directed deletion of the cytoplasmic domain in human amphiregulin did not affect the secretion of the bioactive material (Thorne and Plowman, 1994); however, the cytoplasmic domain is required for basolateral sorting in polarized MadinDarby canine kidney cells (Brown et al., 2001). Whether the lack of a cytoplasmic domain in the short form of porcine amphiregulin affects its cleavage from the membrane or basolateral sorting remains to be determined.

The porcine amphiregulin gene was mapped (Kim et al., 2002) within the previously identified uterine capacity QTL (Rohrer et al., 1999). In the crossbred $\mathrm{M} \times \mathrm{WC}$ population used to identify the QTL, the allele that increases uterine capacity originates from the $\mathrm{M}$ breed. However, no differences in the amphiregulin cDNA sequences, which included the protein coding regions, were obtained from $M(n=2)$ and $\mathrm{WC}(\mathrm{n}=3)$
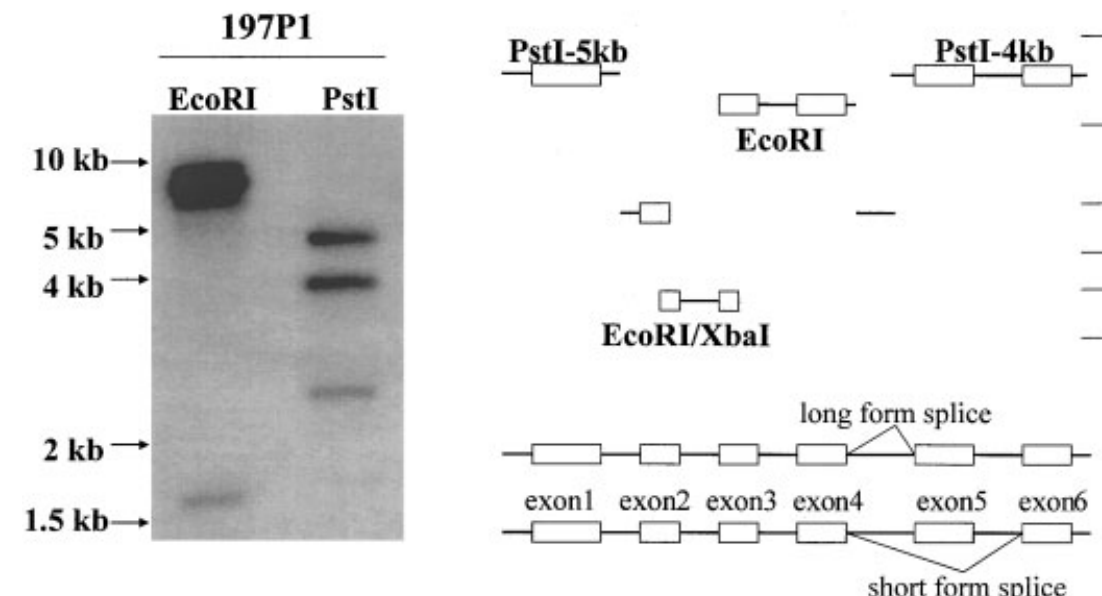

Fig. 5. Identification of the porcine amphiregulin gene organization. A BAC clone containing the amphiregulin gene was digested with EcoRI or PstI, and Southern blotting was performed (left panel). The positive fragments were subcloned and sequenced. The remaining areas were PCR amplified, subcloned, and sequenced. Alignment of sequences revealed the organization of the amphiregulin gene (right panel): exons are indicated in rectangles, while introns, and $5^{\prime}$ and $3^{\prime}$ flanking sequences are indicated in lines. The 5-kb fragment digested with PstI contained $5^{\prime}$ flanking sequence and exon 1 . The 4 -kb fragment digested with PstI contained the exons 5 and 6 . The 1.7-kb fragment digested with EcoRI contained a part of exon 3 and exon 4 . The 3.4-kb EcoRI/XbaI fragment contained a part of intron 1, exon 2, intron 2, and a part of exon 3. Differential splicing of exon 5 for the long and short forms of amphiregulin mRNA is indicated. 
TABLE 3. Exon-Intron Splicing in the Long and Short Form of the Porcine Amphiregulin Gene

\begin{tabular}{lccc}
\hline Exon number & \multicolumn{1}{c}{$5^{\prime}$ splice donor } & $3^{\prime}$ splice acceptor & Amino acid interrupted \\
\hline $\begin{array}{l}\text { Long form } \\
4\end{array}$ & ACA ATC TA gtaagtagg.. & ..ctttgaag C CTT C & Ty r 216 \\
5 & CAGG tttgagttt............. & ..attttcaacag GGTA & none-3' UTR \\
$\begin{array}{l}\text { Short form } \\
4\end{array}$ & ACA ATC TA gtaagtagg.. & ..atttttcaacag GGTA & Sto $\mathrm{p}$ \\
\hline
\end{tabular}

gilts. In contrast, amphiregulin mRNA expression was significantly greater $(P<0.01)$ in WC pigs compared to $\mathrm{M}$ pigs. One could hypothesize that less amphiregulin mRNA expression in the endometrium of M pigs might result in the production of less amphiregulin protein, which could play a role in the slower development of $\mathrm{M}$ conceptuses during early pregnancy (Ford and Youngs, 1993). This could lead to increased uterine capacity and litter size. Thus, differences in endometrial amphiregulin expression between $\mathrm{M}$ and WC pigs are consistent with, but do not prove, that amphiregulin may be responsible for the previously reported QTL. Further experiments to compare gene sequences controlling amphiregulin expression in M and WC gilts are needed to fully evaluate this possibility.

\section{CONCLUSIONS}

In conclusion, the full coding region for porcine amphiregulin precursor cDNA from endometrium is reported. While we were unable to detect mutations in the cDNA sequences that may be responsible for the uterine capacity QTL in either M or WC pigs, the breed difference in amphiregulin mRNA expression is consistent with the hypothesis that amphiregulin is a candidate for the previously reported QTL.

\section{ACKNOWLEDGMENTS}

Authors thank Dr. Emilie Campbell for help in screening the BAC library.

\section{REFERENCES}

Brown CL, Coffey RJ, Dempsey PJ. 2001. The proamphiregulin cytoplasmic domain is required for basolateral sorting, but is not essential for constitutive or stimulus-induced processing in polarized Madin-Darby canine kidney cells. J Biol Chem 276:2953829549.

Christenson RK. 1993. Ovulation rate and embryonic survival in Chinese Meishan and white crossbred pigs. J Anim Sci 71:30603066.

Christenson RK, Leymaster JA, Young LD. 1987. Justification of unilateral hysterectomy-ovariectomy as a model to evaluate uterine capacity in swine. J Anim Sci 65:738-744.

Das SK, Chakraborty I, Paria BC, Wang XN, Plowman G, Dey SK. 1995. Amphiregulin is an implantation-specific and progesteroneregulated gene in the mouse uterus. Mol Endocrinol 9:691-705.
Fahrenkrug SC, Smith TPL, Freking BA, Cho J, White J, Vallet J, Wise T, Rohrer G, Pertea G, Sultana R, Quackenbush J, Keele JW. 2002. Porcine gene discovery by normalized cDNA-library sequencing and EST cluster assembly. Mamm Genome 13:475-478.

Ford SP, Youngs CR. 1993. Early embryonic development in prolific Meishan pigs. J Reprod Fertil Suppl 48:271-278.

Forsyth IA, Taylor JA, Keable S, Turvey A, Lennard S. 1997 Expression of amphiregulin in the sheep mammary gland. Mol Cell Endocrinol 126:41-48.

Johnson GR, Prigent SA, Gullick WJ, Stromberg K. 1993. Characterization of high and low molecular weight forms of amphiregulin that differ in glycosylation and peptide core length. Evidence that the NH2-terminal region is not critical for bioactivity. J Biol Chem 268: $18835-18843$.

Kennedy TG, Brown KD, Vaughan TJ. 1993. Expression of the genes for the epidermal growth factor receptor and its ligands in porcine corpora lutea. Endocrinology 132:1857-1859.

Kim JG, Vallet JL, Christenson RK. 2001. Characterization of uterine epidermal growth factor during early pregnancy in pigs. Domest Anim Endocrinol 20:253-265.

Kim JG, Vallet JL, Rohrer GA, Christenson RK. 2002. Mapping of the porcine AREG and EGF genes to SSC8. Anim Genet 33:314-315.

Kimura H, Fischer WH, Schubert D. 1990. Structure, expression, and function of a schwannoma-derived growth factor. Nature 348:257260.

Plowman GD, Green JM, McDonald VL, Neubauer MG, Disteche CM, Todaro GJ, Shoyab M. 1990. The amphiregulin gene encodes a novel epidermal growth factor-related protein with tumor-inhibitory activity. Mol Cell Biol 10:1969-1981.

Rohrer GA, Ford JJ, Wise TH, Vallet JL, Christenson RK. 1999. Identification of quantitative trait loci affecting female reproductive traits in a multigeneration Meishan-White composite swine population. J Anim Sci 77:1385-1391.

Shaw G, Kamen R. 1986. A conserved AU sequence from the $3^{\prime}$ untranslated region of GM-CSF mRNA mediates selective mRNA degradation. Cell 46:659-667.

Shoyab M, Plowman GD, McDonald VL, Bradley JG, Todaro GJ. 1989. Structure and function of human amphiregulin: A member of the epidermal growth factor family. Science 243:1074-1076.

Thorne BA, Plowman GD. 1994. The heparin-binding domain of amphiregulin necessitates the precursor pro-region for growth factor secretion. Mol Cell Biol 14:1635-1646.

Vallet JL, Klemcke HG, Christenson RK. 2002. Interrelationships among conceptus size, uterine protein secretion, fetal erythropoiesis, and uterine capacity. J Anim Sci 80:729-737.

Vaughan TJ, James PS, Pascall JC, Brown KD. 1993. Molecular cloning and tissue distribution of pig transforming growth factor alpha. Biochem J 296:837-842.

Wilson ME, Biensen NJ, Youngs CR, Ford SP. 1998. Development of Meishan and Yorkshire littermate conceptuses in either a Meishan or Yorkshire uterine environment to day 90 of gestation and to term. Biol Reprod 58:905-910. 